\title{
Has Compensation Become More Flexible?
}

\author{
by \\ Sandra A. Cannon*, Bruce C. Fallick ${ }^{* \dagger}$, Michael Lettau**, and Raven Saks*
}

April 2000

\begin{abstract}
In recent years, numerous observers have argued that global competition, increased reliance on contingent workers, and the breakdown of implicit contracts have made compensation practices in the United States more flexible; in particular, employers have become more concerned with how an employee's pay compares to that in other firms and less concerned with considerations of equity or relative pay within the firm. This paper uses establishment-level data from the Bureau of Labor Statistics' Employment Cost Index program to examine this claim by asking whether the variances of compensation within and between establishments have moved in a more "flexible" direction over the 1980s and 1990s. We find evidence consistent with increased flexibility.
\end{abstract}

"Federal Reserve Board.

${ }^{* *}$ Office of Compensation and Working Conditions, Bureau of Labor Statistics.

${ }^{\dagger}$ Contact author. Federal Reserve Board, Washington, D.C. 20551. E-mail: bfallick@frb.gov.

The views expressed in this paper are those of the authors and do not necessarily represent the views or policies of the Board of Governors of the Federal Reserve System, the Bureau of Labor Statistics, or their staffs. 


\section{Introduction}

The economics and industrial relations literatures offer several explanations for why the labor market does not generally operate as a simple spot market for labor. Internal labor markets, implicit contracts, considerations of equity and relative pay, and more, describe systems of setting compensation that take into account more than individual marginal products and individualistic labor supply curves. ${ }^{1}$ One implication of such descriptions is that firms do not necessarily pay each worker strictly in accordance with his or her best outside option. In particular, there are several reasons why rates of pay for different jobs or workers within a firm may differ less than would be suggested by the "market rates" for their skills or occupations. Groshen (IR 1991), for example, "summarizes five models that explain why an employer might pay a wage premium to all of its employees rather than to particular individuals (p.360)." Similarly, once a pay system is in place, relative pay scales may be preserved despite changes in market conditions.

Of late, however, numerous parties have suggested that global competition and technological change have nudged, if not pushed, employers and workers in the direction of a spot market, resulting in employment relationships characterized by "outsourcing", contingent workers, less job security, reduced worker loyalty, and more task-specific employment contracts. We take that to mean, in large part, that employers feel less constrained to maintain relative pay rates within their firms, while feeling more constrained to "meet the market" for each occupation that they employ. In other words, that pay rates have become less compressed within establishments, while wage rates have become more similar for similar jobs in different establishments.

This paper uses a large, nationally representative sample of jobs within specific establishments from the Bureau of Labor Statistics' (BLS) Employment Cost Index (ECI) program to investigate this proposition indirectly, by examining whether rates of compensation have become less uniform within establishments and more uniform across establishments over the past two decades.

${ }^{1}$ For example, Campbell and Kamlani (1997) outline five theories of "why firms do not appear to adjust wages very much in response to labor market conditions." 
A large literature has documented an increase in the overall dispersion of wages across workers, as opposed to jobs, over the period we study. ${ }^{2}$ Although institutional factors such as decreasing unionization and the erosion of the minimum wage have been cited as partially responsible, most observers have attributed the bulk of the increase in wage dispersion to an increase in the "physical" return to skill, probably due to skill-biased technical change. These two broad explanations - decompression vs. skill-biased technical change - have similar implications for the dispersion of compensation across workers, and across jobs within establishments. But they have different implications for the dispersion of compensation across establishments. These differences allow us to find evidence of decompression even against a backdrop of skill-biased technical change.

\section{Analytical Framework}

As employment relationships move, however modestly, in the direction of spot markets, we would expect to see rates of pay become more responsive to the supply and demand for each occupation or set of skills, and less responsive to the institutions of the firm or considerations of equity, etc.. Intuitively, then, we would expect to see greater variation in pay levels across occupations within establishments, as employers discard policies of wage compression in favor of "meeting the market". Another implication is that we should see less variation in pay levels across establishments within occupations, as firm-specific institutional constraints become less binding, and increased mobility of workers across firms forces employers to be more concerned with workers' opportunity wages elsewhere.

However, other developments, notably skill-biased technical change, could have similar effects. A shift in relative demands for occupations in favor of higher-paid occupations during the period in question would also produce an increase in the variation in pay levels across occupations within establishments. However, we would not necessarily expect such a shift to influence the between-establishment variation in the same way as a policy of "decompression" would.

A fully specified model is beyond the scope of this paper. However, our analytical

${ }^{2}$ In broad terms, the differences in the growth rates of pay among industry and occupation groups in the ECI is consistent with these findings (Lettau 1999). 
framework can be illustrated by a simple representation of pay-setting behavior.

Let $\mathrm{w}_{\mathrm{i}}^{\mathrm{s}}=\log$ of the rate of pay for occupation $\mathrm{s}$ in establishment $\mathrm{i}$,

$\mathrm{w}_{\mathrm{i}}=$ the average log pay rate in establishment $\mathrm{i}$,

$\mathrm{mrp}_{\mathrm{i}}^{\mathrm{s}}=$ the $\log$ of the marginal revenue product of occupation s in establishment $\mathrm{i}$,

$\operatorname{mrp}_{\mathrm{i}}=$ the average log marginal revenue product in establishment $\mathrm{i}$, and

$\mathrm{e}_{\mathrm{i}}=\mathrm{a}$ term representing the establishment's ability to pay, profit-sharing, or other establishment-specific shared determinant of pay.

Assume that (1) $\mathrm{w}_{\mathrm{i}}^{\mathrm{s}}=(1-\alpha)^{*}\left(\mathrm{mrp}_{\mathrm{i}}^{\mathrm{s}}+\beta^{*} \mathrm{e}_{\mathrm{i}}\right)+\alpha^{*} \mathrm{w}_{\mathrm{i}}$.

That is, the rate of pay for an occupation in an establishment deviates from the mrp for that occupation in two ways. The first is that there is some degree of wage compression across occupations, indexed by $\alpha$. This may arise out of notions of fairness (Akerlof 1984, Akerlof and Yellen 1988 and 1990), worker harmony (Lazear 1986) or from the value workers place on relative pay (Frank 1984). The second is that the firm shares quasi-rents or profits with workers, whether formally or not (Hildreth and Oswald 1997, Katz and Summers 1989), with the degree of sharing indicated by $\beta$.

Averaging (1) over occupations within an establishment and substituting back in yields

(2) $\mathrm{w}_{\mathrm{i}}^{\mathrm{s}}=\beta^{*} \mathrm{e}_{\mathrm{i}}+(1-\alpha)^{*} \mathrm{mrp} \mathrm{p}_{\mathrm{i}}^{\mathrm{s}}+\alpha^{*} \mathrm{mrp} \mathrm{p}_{\mathrm{i}}$.

The total variance of $\mathrm{w}_{\mathrm{i}}^{\mathrm{s}}$ can be divided into the mean of the variance across occupations (s) within establishments (i), and the variance across establishments (i) of the mean within each establishment. Let us treat each in turn.

The variance of the level of $w$ across occupations within an establishment is

(3) $\operatorname{var}_{i}\left(\mathrm{w}_{\mathrm{i}}^{\mathrm{s}}\right)=(1-\alpha)^{2 *} \operatorname{var}_{i}\left(\operatorname{mrp}_{\mathrm{i}}^{\mathrm{s}}\right)$.

where the subscript $\mathrm{i}$ on the variance means "within establishment i". Obviously, 
(4) $\partial \operatorname{var}_{i}\left(\mathrm{w}_{\mathrm{i}}^{\mathrm{s}}\right) / \partial \alpha=-2(1-\alpha) * \operatorname{var}_{\mathrm{i}}\left(\operatorname{mrp}_{\mathrm{i}}^{\mathrm{s}}\right)<0$.

Therefore, as wage-setting moves away from institutional considerations that favor wage compression, we should expect the within-establishment variance of pay rates to rise.

The variance across establishments of the establishment-mean level of w (averaged over all occupations) is

(5) $\operatorname{var}\left(\mathrm{w}_{\mathrm{i}}\right)=\beta^{2 *} \operatorname{var}\left(\mathrm{e}_{\mathrm{i}}\right)+\operatorname{var}\left(\mathrm{mrp}_{\mathrm{i}}\right)+2 \beta^{*} \operatorname{cov}\left(\mathrm{e}_{\mathrm{i}}, \operatorname{mrp}_{\mathrm{i}}\right)$.

Naturally, this variance is unaffected by the degree of wage compression within establishments, as long as the establishment's mean wage is unaffected. Because the overall variance is the sum of the within-establishment and between-establishment variances, this implies that decompression should increase the overall variance in pay levels (across occupation-establishment cells) as well.

The variance of $\mathrm{w}$ across establishments within a given occupation $\mathrm{s}$ is

(6) $\operatorname{var}^{\mathrm{s}}\left(\mathrm{w}_{\mathrm{i}}^{\mathrm{s}}\right)=\beta^{2 *} \operatorname{var}\left(\mathrm{e}_{\mathrm{i}}\right)+(1-\alpha)^{2 *} \operatorname{var}^{\mathrm{s}}\left(\operatorname{mrp}_{\mathrm{i}}^{\mathrm{s}}\right)+\alpha^{2 *} \operatorname{var}\left(\mathrm{mrp}_{\mathrm{i}}\right)+2 \beta(1-\alpha)^{*} \operatorname{cov}\left(\mathrm{e}_{\mathrm{i}}, \operatorname{mrp}_{\mathrm{i}}^{\mathrm{s}}\right)+$

$$
2 \beta \alpha^{*} \operatorname{cov}\left(\mathrm{e}_{\mathrm{i}}, \mathrm{mrp}_{\mathrm{i}}\right)+2 \alpha(1-\alpha)^{*} \operatorname{cov}\left(\mathrm{mrp}_{\mathrm{i}}^{\mathrm{s}}, \mathrm{mrp}_{\mathrm{i}}\right)
$$

where the superscript s on the variance means "within occupation s". Therefore,

$$
\begin{gathered}
\text { (7) } \partial \operatorname{var}^{\mathrm{s}}\left(\mathrm{w}_{\mathrm{i}}^{\mathrm{s}}\right) / \partial \alpha=-2(1-\alpha) * \operatorname{var}^{\mathrm{s}}\left(\operatorname{mrp}_{\mathrm{i}}^{\mathrm{s}}\right)+2 \alpha^{*} \operatorname{var}\left(\operatorname{mrp}_{\mathrm{i}}\right)-2 \beta^{*} \operatorname{cov}^{\mathrm{s}}\left(\mathrm{e}_{\mathrm{i}}, \operatorname{mrp}_{\mathrm{i}}^{\mathrm{s}}\right)+ \\
2 \beta^{*} \operatorname{cov}^{\mathrm{s}}\left(\mathrm{e}_{\mathrm{i}}, \operatorname{mrp}_{\mathrm{i}}\right)+2(1-2 \alpha)^{*} \operatorname{cov}^{\mathrm{s}}\left(\operatorname{mrp}_{\mathrm{i}}^{\mathrm{s}}, \operatorname{mrp}_{\mathrm{i}}\right)
\end{gathered}
$$

In the extreme case that the mrp of an occupation is the same in all establishments, this derivative becomes $2 \alpha^{*} \operatorname{var}\left(m r p_{\mathrm{i}}\right)+2 \beta^{*} \operatorname{cov}^{\mathrm{s}}\left(\mathrm{e}_{\mathrm{i}}, \mathrm{mrp}_{\mathrm{i}}\right)$. The first term is positive, and the second term is probably positive as well, because there would seem to be more "rents" to share, and the workers are in a better position to win a share of them, when the workers are higher skilled. Thus, the derivative can be reasonably assumed to be positive. As we move sufficiently away from this extreme, the sign of the derivative becomes ambiguous, but we consider it likely that the 
variation in mrp within occupation is small relative to the overall variance in mrp across occupations and establishments. Therefore, as wage-setting moves away from institutional considerations that favor wage compression, we would expect variance across establishments but within an occupation to fall. ${ }^{3}$

We can expand this representation of pay-setting in a simple fashion to incorporate an increase in the productivity of skill. Let $\mathrm{k}_{\mathrm{i}}^{\mathrm{s}}$ be the skill level of occupation $\mathrm{s}$ in establishment $\mathrm{i}$. Let $r$ be the physical return to skill such that $\operatorname{mrp}_{i}{ }^{s}=\mathrm{rk}_{\mathrm{i}}^{\mathrm{s}}$. Then

(3') $\operatorname{var}_{i}\left(\mathrm{w}_{\mathrm{i}}^{\mathrm{s}}\right)=(1-\alpha)^{2} \mathrm{r}^{2} \operatorname{var}_{\mathrm{i}}\left(\mathrm{k}_{\mathrm{i}}^{\mathrm{s}}\right)$ and

(8) $\partial \operatorname{var}_{i}\left(w_{i}^{s}\right) / \partial r=(2 r) \operatorname{var}_{i}\left(k_{i}^{s}\right)>0$. That is, we would expect the within-establishment variance of pay rates to rise as the return to skill rises.

The between establishment variance becomes

$\left(5^{\prime}\right) \operatorname{var}\left(\mathrm{w}_{\mathrm{i}}\right)=\beta^{2 *} \operatorname{var}\left(\mathrm{e}_{\mathrm{i}}\right)+\mathrm{r}^{2} \operatorname{var}\left(\mathrm{k}_{\mathrm{i}}\right)+2 \beta \mathrm{r}^{*} \operatorname{cov}\left(\mathrm{e}_{\mathrm{i}}, \mathrm{k}_{\mathrm{i}}\right)$, and

(9) $\partial \operatorname{var}\left(\mathrm{w}_{\mathrm{i}}\right) / \partial \mathrm{r}=2 \mathrm{r} * \operatorname{var}\left(\mathrm{k}_{\mathrm{i}}\right)+2 \beta \operatorname{cov}\left(\mathrm{e}_{\mathrm{i}}, \mathrm{k}_{\mathrm{i}}\right)>0$, That is, we would expect the between-

establishment variance of average pay rates, which we would expect to be unaffected by decompression alone, to rise as the return to skill rises.

The variance of $\mathrm{w}$ across establishments within a given occupation $\mathrm{s}$ becomes

$\left(6^{\prime}\right) \operatorname{var}^{\mathrm{s}}\left(\mathrm{w}_{\mathrm{i}}^{\mathrm{s}}\right)=\beta^{2 *} \operatorname{var}\left(\mathrm{e}_{\mathrm{i}}\right)+(1-\alpha)^{2} \mathrm{r}^{2 *} \operatorname{var}^{\mathrm{s}}\left(\mathrm{k}_{\mathrm{i}}^{\mathrm{s}}\right)+\alpha^{2} \mathrm{r}^{2 *} \operatorname{var}\left(\mathrm{k}_{\mathrm{i}}\right)+2 \beta(1-\alpha) \mathrm{r}^{*} \operatorname{cov}\left(\mathrm{e}_{\mathrm{i}}, \mathrm{k}_{\mathrm{i}}^{\mathrm{s}}\right)+$

$$
2 \beta \alpha \mathrm{r}^{*} \operatorname{cov}\left(\mathrm{e}_{\mathrm{i}}, \mathrm{k}_{\mathrm{i}}\right)+2 \alpha(1-\alpha) \mathrm{r}^{2} * \operatorname{cov}\left(\mathrm{k}_{\mathrm{i}}^{\mathrm{s}}, \mathrm{k}_{\mathrm{i}}\right) \text {, and }
$$

(10) $\partial \operatorname{var}^{\mathrm{s}}\left(\mathrm{w}_{\mathrm{i}}^{\mathrm{s}}\right) / \partial \mathrm{r}=2(1-\alpha)^{2} \mathrm{r}^{*} \operatorname{var}^{\mathrm{s}}\left(\mathrm{k}_{\mathrm{i}}^{\mathrm{s}}\right)+2 \alpha^{2} \mathrm{r}^{*} \operatorname{var}\left(\mathrm{k}_{\mathrm{i}}\right)+2 \beta(1-\alpha) * \operatorname{cov}\left(\mathrm{e}_{\mathrm{i}}, \mathrm{k}_{\mathrm{i}}^{\mathrm{s}}\right)+$

$2 \beta \alpha^{*} \operatorname{cov}\left(\mathrm{e}_{\mathrm{i}}, \mathrm{k}_{\mathrm{i}}\right)+4 \alpha(1-\alpha) \mathrm{r}^{*} \operatorname{cov}\left(\mathrm{k}_{\mathrm{i}}^{\mathrm{s}}, \mathrm{k}_{\mathrm{i}}\right)$, which is almost surely positive. That is, we would expect the average between-establishment variance of pay rates within occupations to rise as the return to skill rises; the opposite of the movement we would expect as a result of decompression.

In sum, we would expect a policy of decompression associated with a decline in the importance of institutional and internal factors relative to outside market conditions, to result in i) an increase in the average variance of pay levels across occupations within establishments,

${ }^{3}$ However, the between-establishment/within-occupation variance should also fall if establishments become more similar in their shared "rents", their distributions of occupations, their mrp for a given occupation, or the covariances among these elements. 
ii) no change in the variance of average pay levels across establishments,

iii) a decrease in the average variance of pay levels across establishments within occupations.

We would expect an increase in the marginal product of skill to result in

i) an increase in the average variance of pay levels across occupations within establishments,

ii) an increase in the variance of average pay levels across establishments,

iii) an increase in the average variance of pay levels across establishments within occupations.

Other researchers have suggested other implications based on more complex views of pay setting. Theoretical models by Caselli (1999) and Kremer and Maskin (1996) have implications for changes in wage dispersion based on the effects of skill-biased technical change and sorting by skill level. Skill-biased technical change affects wage dispersion by changing the way establishments employ labor. If a new technology arrives which requires new skills and those skills are costly to acquire, not all workers will choose to learn to use the new technology. This results in two types of workers: highly skilled workers who can work with the new technology and lowly skilled workers who cannot. Employers then decide what mix of skills are necessary for efficient production at their firm. In some establishments, a wide range of tasks requires a wide range of skills which would lead an employer to have a mixed workforce with less segregation by skill. If workers are paid their marginal product, these establishments will have a very high within-establishment wage dispersion matching the dispersion of marginal products. The more similar are the tasks at an establishment, the more complementarities arise from having similar workers at a given firm. This would be seen as a more compressed wage structure since the employees have more similar skills.

Skill-biased technical change should then lead to an increase in across establishment wage variation and a decrease in within establishment wage variation. Because the sample of occupations is fixed at the beginning of sample period in the ECI, compositional changes in the mix of jobs within an establishment will not be seen. If segregation by skill is occurring, however, then as new firms replenish the sample, they would have more similar workforces due to the skillbiased technical change.

In this case, we would expect to see

i) decrease in the average variance of pay levels across occupations within establishments (as skill- 
segregated establishments replace less segregated establishments),

ii) an increase in the variance of average pay levels across establishments (due to sorting),

iii) an increase in the average variance of pay levels across establishments within occupations (as high skilled workers at high skilled plants are more productive than high skilled workers at low skilled plants).

The following table summarizes the implications of each class of hypotheses for the trends in variances within and between establishments:

\begin{tabular}{|c|c|c|c|}
\hline \multicolumn{4}{|c|}{ Implications for Variances } \\
\hline Hypothesis & $\begin{array}{c}\text { Within } \\
\text { establishment }\end{array}$ & $\begin{array}{c}\text { Between } \\
\text { establishment }\end{array}$ & $\begin{array}{c}\text { Between estab., } \\
\text { within occupation }\end{array}$ \\
\hline decompression & increase & no change & decrease \\
\hline $\begin{array}{c}\text { skill-biased change } \\
\text { without sorting }\end{array}$ & increase & increase & increase \\
\hline $\begin{array}{c}\text { sorting driven by } \\
\text { skill-biased change }\end{array}$ & decrease & increase & increase \\
\hline
\end{tabular}

Of course, decompression, technical change, and sorting may all have taken place to one degree or another over the course of the past twenty years. But the table indicates that an overall decrease in variance between establishments for similar jobs should be taken as evidence that decompression has been the dominant factor, while an overall decrease in within-establishment variance would argue in favor of sorting as the dominant influence, and an increase in both variances would give the leading role to skill-biased technical change itself.

\section{Data}

Each quarter, the Employment Cost Index (ECI) program collects data on various components of compensation per hour for a large number of jobs representing specific occupations within more than 4,000 private establishments throughout the United States. An establishment typically remains in the sample for about 20 consecutive quarters before being replaced by another in the same industry. The ECI also includes data for state and local 
governments, but in this study we use only the data pertaining to private industry. Note that data are collected for only a sample of jobs within each establishment, with a median of 5 jobs per establishment. The jobs are selected randomly, in proportion to the number of workers in that job at the establishment, and so are likely to be those in which the establishment's workers are concentrated. However, they do not represent a census of jobs in the establishment. Each establishment is assigned a weight at initialization, which does not change over time.

We use the micro-level data from the ECI as an unbalanced panel of observations on jobs within establishments. The sample covers the period 1980:Q1 to 1999:Q2. We began with the same sample of observations as used to calculated the published ECI (which, for example, excludes observations without positive wages and salaries per hour). However, the sampling scheme for the ECI results in only one or two jobs being sampled for some establishments. Because one focus of this paper is on variances across jobs, and since these variances are not estimated well from just a couple of jobs, we restricted our sample to those establishments in which at least 4 jobs were sampled. In order to avoid complications arising from the seasonality of pay-setting, we also restrict our analysis to data that refers to the same month in each year to June, in particular.

In addition, we trimmed the data set by excluding observations with wages and salaries per hour in the top and bottom 0.5 percent of the unrestricted distribution in each year. Over the entire range of the sample, this had the effect of dropping all observations with wages and salaries per hour less than $\$ 2.30$ or greater than $\$ 75.00$. We further trimmed observations with voluntary benefits (defined below) in the top 0.5 percent of the distribution in each year.

In the end we are left with a sample comprising 312,988 observations of jobs within establishments over 19 years. The number of observations ranges from 6,728 in 1980 to 22,404 in 1990, and the number of establishments represented ranges from 1,030 in 1980 to 3,809 in 1999. Some summary statistics for the sample are shown in table 1.

For the purposes of this study we exclude from compensation those components of benefits that are mandated by law. These include Social Security, Medicare, railroad retirement, 
Federal unemployment insurance, state unemployment insurance, and workers' compensation. ${ }^{4}$ The remaining benefits we term "voluntary". Voluntary benefits comprise overtime, paid vacations, paid holidays, paid sick leave, other paid leave, shift differentials, non-production bonuses, severance pay, supplemental unemployment compensation, life insurance, health insurance, sickness and accident insurance, and retirement and savings plans. ${ }^{5}$ Voluntary compensation can then be defined as wages and salaries plus voluntary benefits. ${ }^{6}$

BLS imputed values for wages and salaries per hour for the roughly eight percent of the observations that were missing data due to non-response or other reasons. ${ }^{7}$ Some components of benefits were more commonly imputed. ${ }^{8}$ We include both imputed and non-imputed data in our analysis.

We analyze the log of the level of compensation or its components rather than level itself. This serves to make the variance insensitive to the general nominal level of compensation. When analyzing a component of compensation for which any non-trimmed observation has a zero value, we add (year by year) the mean of that component to every observation.

Figure 1 shows the means and variances of the log levels of voluntary compensation for each year in our sample. Of course, the mean levels (which correspond to a limited degree with the BLS's published estimates of Employer Costs for Employee Compensation), rise pretty much

${ }^{4}$ Railroad retirement benefits appeared as a separate category in the ECI only until June 1995, and medicare taxes were included as a separate category only beginning June 1995.

${ }^{5}$ In June 1995, the ECI program reclassified various pension, retirement, savings, and thrift plans into the categories of defined benefit retirement defined contribution retirement plans. This change did not, however, affect the aggregate of these categories.

${ }^{6}$ Of course, several of these components of compensation are voluntary only within limits prescribed by various laws and regulations.

${ }^{7}$ In these cases, an initial value was collected, but values were imputed for quarters for which changes from the previous quarter were no reported.

${ }^{8}$ Of the components of benefits that we will highlight below, ten percent of observations have imputed nonproduction bonuses, fifteen percent have imputed health insurance, and thirteen percent have imputed retirement \& savings. 
throughout the period. ${ }^{9}$ However, the variance of the log level also trends upwards, at least over the 1980s. Might this increase in the variance of voluntary compensation be a reflection of greater flexibility in pay-setting?

\section{Variances}

We argued above that the flexibility of compensation practices, in the particular sense of the ability or willingness of employers to tailor compensation to the market conditions relevant to each job individually, should manifest itself in the degree of variation in rates of compensation among jobs or establishments. In particular, we argued that as compensation practices move in the direction of spot markets, we should expect to see the variance of compensation across occupations within establishments rise, and to see the variance across establishments within occupation fall, while leaving the variance across establishments means relatively unaffected. In this section we examine how these quantities have changed over time, before moving on to regression analysis in the next section.

We first look at the variance in compensation across jobs within establishments. We compute the mean across establishments of the variance across jobs of the log level of compensation within each establishment. That is, we compute

$$
M V_{t}=E_{i}\left(V_{j}\left(C_{i j t}\right)\right)
$$

where $\mathrm{i}$ indexes establishments, $\mathrm{j}$ indexes jobs within establishments, $\mathrm{t}$ indexes time, and $\mathrm{c}$ is the log level of compensation (or in a component of compensation).

In computing the variance across jobs within an establishment, we would like to weight each job by the proportion of the establishment's workforce that the job represents, as well as the relative size of the establishment as a whole. Our data do not, unfortunately, include information

${ }^{9}$ Of course, the published data are not restricted to what we term voluntary benefits. 
on the proportion of an establishment's workforce in each job within the establishment, but the sampling scheme is, to some degree, self-weighting. The data do include weights for the total number of workers in each establishment. We use these weights to compute the weighted mean of the variances across establishments.

The left side of figure 2 shows MV annually for wages \& salaries and voluntary benefits. ${ }^{10}$ Both variances have increased over the two decades shown. These uptrends are consistent with decompression, but the bulk of the increase in the $(\log )$ level of wages $\&$ salaries took place during the 1980s, when the largest increases in dispersion across persons have been found and before the anecdotal reports of more flexible wage-setting gained quite the prominence that they have since. On the other hand, the increase in the variance for benefits was concentrated in the 1990s.

To give a sense of the magnitude of the increase in variance in the ECI data, it is larger than the widely noted increase in across-person wage inequality observed in the Current Population Survey (CPS). Juhn, Murphy, and Pierce (1993), for example, report that the variance of log hourly wages in the CPS rises from .28 in 1982 to .32 in 1988 . Over the same period, the variance of $\log$ wages \& salaries per hour rises still more, from .23 in 1982 to .3 in $1988 .^{11}$

We calculate the variance across establishments of the mean log level of compensation within each establishment, that is,

$$
V M_{t}=V_{i}\left(E_{j}\left(C_{i j t}\right)\right)
$$

\footnotetext{
${ }^{10}$ Because wages and salaries are such a large proportion of voluntary compensation, in most figures we include only graphs for wages and salaries and for benefits.

${ }^{11}$ Although there are other differences in concept and measurement that may render data from these two sources less than strictly comparable, in general one would expect the variance in the ECI would be lower than the variance in the CPS data, because the latter captures variation across individuals within jobs, in addition to the variation across jobs and establishments captured in the ECI data.
} 
These variances, shown on the right side of figure 2, also rose over the period, with the increase for wages \& salaries heavily concentrated in the early 1980s. If decompression were the only thing going on, we would not expect to see these variances increase.

Another way to summarize the evolution of within-establishment and betweenestablishment variances is to look at a more general decomposition of the overall variance. Figure 3 apportions the total variance across \{job x establishment \} cells into the share attributable to industry at the 1- to 4- digit levels, the share attributable to the establishment, and the residual variance, which is attributable to jobs within establishments. ${ }^{12}$ We do this in a nonparametric fashion by attributing to 1-digit industry the amount of the variance that can be "explained" by 1digit industry in an OLS regression; attributing to 2-digit industry the difference between the amount that can be explained by 2-digit industry and the amount that can be explained by 1-digit industry, and so on, treating the establishment as one level of industry disaggregation beyond the 4-digit level. The variance that cannot be explained by the establishment in an OLS regression we attribute to jobs within establishments.

Concentrating first on wages \& salaries, it is notable how much of the variance can be explained by industry alone, without reference to the individual establishment or job. The onedigit industry alone can account for about $1 / 6$ of the total variance on average, and the four-digit industry can (cumulatively) account for slightly more than half (53 percent on average). Of the remaining 47 percent, the establishment and the job within the establishment account for roughly equal shares. For our purposes, however, the important point is that the share attributed to the job has risen relative to the share attributed to the establishment. While this is consistent with the hypothesis of decompression, most of the change in these relative shares took place during the 1980s, which may not be the most likely timing under that hypothesis.

The establishment assumes greater prominence in explaining the variance of (log) voluntary benefits. Nevertheless, as was the case with wages $\&$ salaries, the share attributed to

\footnotetext{
${ }^{12}$ The 1-digit industry breakdowns used here comprises nine "major industry groups": mining; construction; nondurable manufacturing; durable manufacturing; transportation, communications, and public utilities; wholesale trade; retail trade; finance, insurance, and real estate; and services. The 2-, 3-, and 4-digit industries refer to SIC codes.
} 
the job rises over time while the share attributed to the establishment within industry has fallen. In this case, the change in relative shares continued into the mid-1990s.

We next calculate the variance across establishments but within occupations. We argued in section II that this variance should decline under the decompression hypothesis, while the hypotheses related to skill-biased technical change imply that this variance should rise.

Unfortunately, for most of the sample period, we can identify the occupation of a job only at the level of the major occupation group (MOG), ${ }^{13}$ which is a much coarser taxonomy than we would like. Only beginning in 1993 can we identify the occupation of each job at a finer level of disaggregation (3-digit Census occupations). Partly to make up for this deficiency, and more generally to hone in on categories within which workers' mobility across establishments is likely to be great, we further divided the sample by industry. Thus, figure 4 shows the average variance across establishments within MOG and 3-digit SIC. ${ }^{14}$ (For comparison, the figure also includes the average variance within detailed industry and 3-digit SIC for those few years for which this information is available.) No downtrend appears in the variances for either wages \& salaries or voluntary benefits, as we might expect to see if decompression were the dominant development over this period. At least for wages \& salaries, one may discern an uptilt in the first half of the 1980 s -- when the increase in across-person wage inequality was most pronounced, and a bit of a drift down thereafter, but no consistent or pronounced pattern in either direction is evident.

\section{Panel Regressions}

The decompositions presented thus far provide little support for the notion that compensation has become more flexible, in the particular sense laid out above, over the period 1980-1999. In this section we subject the question to greater scrutiny by exploiting the panel

\footnotetext{
${ }^{13}$ Professional and technical; executive and administrative; sales, administrative support, precision production and repair; machine operator; transportation; handling and labor; service occupations.

${ }^{14}$ In principle, a finer level of industry disaggregation would be preferable. We know the 4-digit industry of each establishment. However, the sizes of the 4-digit industry $\mathrm{x}$ occupation cells tend to be unacceptably small. The choice of 3-digit industry balances the demands of theory with the adequacy of the data.
} 
nature of the data.

In order to keep the sample representative of the economy, after a time each establishment in the sample is replaced by another in the same industry. This periodic "replenishment" means that the changes we observe over time my be due to changes in the behavior of individual establishments, or to changes in the composition of the sample as establishments with one set of compensation practices are replaced by establishments with different practices. ${ }^{15}$ We can distinguish between these two avenues for change by controlling for observed characteristics of the establishments and by including establishment-effects in the estimation. This also allows us to abstract from jumps in the variances, especially within particular industries, that replenishment may create at some points in the sample. ${ }^{16}$

\section{Within-establishment variance}

We begin by controlling for the observed attributes of each establishment. Using weighted OLS, we estimated

(11) $\mathrm{V}_{\mathrm{i}, \mathrm{t}}=\alpha+\mathrm{X}_{\mathrm{i}} \beta+\mathrm{Y}_{\mathrm{t}} \gamma+\mathrm{Z}_{\mathrm{i}, \mathrm{t}}+\varepsilon_{\mathrm{i}, \mathrm{t}}$, where

$\mathrm{i}$ indexes establishments, $\mathrm{t}$ indexes years;

$\mathrm{V}_{\mathrm{i}, \mathrm{t}}=$ within-establishment variance across jobs of the log level of compensation (or its components) for establishment $i$ in quarter $t$;

$X_{i}$ is a vector of time-invariant attributes of establishment $i$, measured at the time the establishment entered the sample, comprising

${ }^{15}$ Because observations are defined as occupations or jobs within establishments, our data are not directly affected by changes in the mix of jobs within a given establishment. However, as noted above, the characteristics of the workers in a given job may change over time, which may contaminate our results.

${ }^{16}$ The ECI program spreads out the replenishment of the establishments in an industry over several quarters. This sample design ensures that all industries are adequately represented in the three-month changes that make up the published ECI. But the levels may change abruptly when a large part of an industry is replenished between our year-apart observations. 
SMSA $=$ a dummy variable equal to 1 if the establishment is located in an SMSA,

STATE $=$ a vector of dummy variables for the state in which the establishment is located,

$\mathrm{UNION}=$ a dummy variable equal to 1 if any of the jobs sampled in the establishment is covered by a union contract,

LARGE $=$ a dummy variable equal to 1 if the establishment employed more than 500 workers, SMALL $=$ a dummy variable equal to 1 if the establishment employed fewer than 100,

MID = a vector of dummy variables for major industry division, and

$\mathrm{MOG}=\mathrm{a}$ vector of dummy variables equal to 1 if a major occupation group is represented among the jobs sampled at the establishment; ${ }^{17}$

$Y_{t}$ is a vector of dummy variables for the years in the sample;

$\mathrm{Z}_{\mathrm{i}, \mathrm{t}}$ is a vector of variables that vary across time and establishment. At this point, it includes only UR_STATE $=$ the unemployment rate in the state in which the establishment in located.

The results for selected variables are shown in the first three columns of table 2. Of particular note is that establishments with at least one unionized occupation surveyed show more dispersion in the levels of compensation than establishments with no unionized occupations surveyed -- a result that is out of step with the conventional wisdom. ${ }^{18}$ The coefficients are otherwise unremarkable. In results not shown, dispersion in the levels tends to be greatest in the services and finance, insurance, and real estate industries, and least in transportation, communications, and public utilities.

In principle, equation (11) allows the observed attributes of establishments to change over

\footnotetext{
${ }^{17}$ The regressions also contain a variable for the number of occupations represented in our data for each establishment.

${ }^{18}$ Indeed, the average variance is smaller in establishments with at least one unionized occupation if we look at the data without conditioning on anything else. But the coefficient turns positive once we control for the industry and occupation mix. Even here, as it turns out, establishments in service industries drive the higher dispersion within establishments with some unionization. Excluding these establishments leads to lower dispersion in compensation within atleast-partially unionized establishments, and this lower dispersion is particularly pronounced among manufacturing industries.
} 
time. However, by design of the ECI program, the elements of $X$ in equation (11) are fixed when an establishment enters the sample. Any evolution of these attributes will only show up only as the sample is replenished.

Of course, our data likely omit many relevant attributes of the establishments. To account for this possibility, we estimated a version of equation (11) using fixed establishment-effects, $\alpha_{i}$, so that the estimates derive solely from changes over time within establishments.

(11') $\mathrm{V}_{\mathrm{i}, \mathrm{t}}=\alpha_{\mathrm{i}}+\mathrm{Y}_{\mathrm{t}} \gamma+\mathrm{Z}_{\mathrm{i}, \mathrm{t}}+\varepsilon_{\mathrm{i}, \mathrm{t}}$,

Obviously, we must rely on equation (11) to provide estimates of which types of establishments tend to have greater or lesser dispersion, but (11') gives us the cleanest reading on trends in dispersion at individual establishments over time.

Our main focus here is on whether there has been a trend in the variances of pay. To answer this question, the coefficients on the year dummies are plotted in figure 5. When the establishment effects are not included in the regression (the solid lines), there is an upward trend in the variances of $(\log )$ wages \& salaries, and an upward trend in the variance of $(\log )$ benefits as well.

The coefficients on the year dummies from the regression of wages \& salaries jumps up notably in 1990. However, when establishment effects are included (the dashed line), the jump fades away. More generally, the fixed-effects estimates for wages \& salaries also rise over the period, but the overall increase is considerably smaller than the increase without the fixed-effects. It is also spread more evenly over the two decades. If we are to take the upward trend as an indication of increased flexibility exercised by employers exercise in setting pay, then one may interpret the difference between the two regressions as indicating that there has been some increase in flexibility, on average, within establishments, but that over time establishments exhibiting less flexibility have been replaced by establishments exhibiting more flexibility, and this shift in composition is reflected in the changing make-up of the ECI sample as that sample is replenished to remain current.

The fixed-effects also reduce the upward slope in the estimates for voluntary benefits. In 
fact, there is little increase at all in the year coefficients when fixed-effects are included in the regression.

Figure 6 shows results for each of several components of benefits that might be expected to have figured prominently in any change in the flexibility of wage-setting: nonproduction bonuses, retirement plans, and health insurance. Nonproduction bonuses show no increase in variance, and show a downward trend when fixed effects are taken out. The variances for both retirement $\&$ savings and health insurance trend upward, like total voluntary benefits, but the increase is attenuated by the establishment effects. ${ }^{19}$ Keep in mind that these data reflect only the employers' costs for health insurance and pension plans, not any part of the costs that are paid by employees. Also, the component for retirement plans lumps together defined benefit and defined contribution-type. Particularly for defined-benefit type plans, then, this component will reflect conditions (stock market valuations, for example) that affect employers' costs even if they do not affect employees' expected benefits.

\section{Between-establishment variance}

The estimated upward movement in the within-establishment variance is consistent with either an increase in flexibility or skill-biased technical change in its purer form, as opposed to the sorting hypothesis of skill-biased technical change, as the dominant influence over this period. However, decompression and skill-bias have different implications for the between-establishment, within-occupation-and-industry variances, to which we now turn.

The estimated trends in between-establishment/within-industry/within-MOG variation, derived from versions of equations (11) and (11'), are shown in figure 7. As in section IV, we are interested in the variation between similar establishments for similar jobs, so the dependent variable in these regressions refers to the variance between establishments within each 3-digit industry, calculated separately for jobs in each major occupation group (MOG). That is, any jobs within an establishment that are in the same MOG in a given year are averaged together, resulting

\footnotetext{
${ }^{19}$ The increase in the variance of health insurance appears to be driven by changes in its incidence. A similar pattern appears if the level of health insurance costs is replaced by a $(0,1)$ variable for the presence of any employer costs for health insurance.
} 
in one observation per establishment for each MOG in each year. ${ }^{20}$ These observations are grouped into cells defined by the yyear x MOG of the jobs x 3-digit industry of the establishment , and the variance is calculated within each cell. The dependent variable in the regression is this within-cell (between-establishment) variance.

Also, as before, we use a version of (11') to take account of the effects of the periodic replenishment of the sample. When the individual establishment was the unit of analysis, this was done by including fixed effects for each establishment. Here we define something analogous. For each replenishment cycle, establishments in a particular set of industries are scheduled to be replaced. Therefore, it is possible to divide the observations for each 3-digit industry into "replenishment groups". That is, if the establishments in industry A are replaced in, say, 1987 and 1993, then the observations in industry A for years 1980-1986 would constitute one replenishment group, the observations in industry A for years 1987-1992 would constitute a second replenishment group, the observations for industry A for years 1993-1999 would constitute a third replenishment group. By including fixed effects for each replenishment group in the regression, we control for the effects of replenishment on the aggregate trends. Of course, this procedure does not control for other forms of attrition, but we expect attrition outside of replenishment to be a minor problem.

As in (11') above, the only variables on the right-hand side of these regressions refer to the year and to the state unemployment rate. Here, however, the latter must be modified to apply to using the 3-digit industry rather than the establishment as the unit of analysis. Accordingly, we include two variables for the state unemployment rate: the mean and the variance of the state unemployment rates of the establishments in the industry in each year.

For wages \& salaries, the regressions of between-establishment, within-occupation-andindustry variances produce year coefficients that move up during the 1980s, and drift back down over the following ten years. This would be consistent with the idea that skill-biased change was the dominant factor during the period of the most notable increase in across-person wage inequality, while decompression has been the dominant theme thereafter. However, the fixed-

${ }^{20}$ Of course, not every MOG is represented in every establishment. 
effects estimates decline pretty steadily over the twenty years. If skill-biased change were the dominant factor during the 1980s, it would have to be the case that the widening of skill differentials and increase in residual variance across persons that we saw in that decade came about primarily because the entry of new establishments increased the between-establishment variance for similar jobs.

The results for benefits are not as smooth, but are similar to the results for wages $\&$ salaries in that the fixed-effects estimates fall gradually over the 20 year sample period. The declining variance between-establishments but within MOGs and industries argues in favor of the notion that compensation practices have become more flexible in the sense of moving away from internal considerations that favor wage compression.

\section{Cyclicality}

Once we abstract from changes in the composition of establishments in the sample, and presumably in the economy, we find that the within-establishment variance of both wages \& salaries and of benefits has risen over the past twenty years, primarily between the mid-1980s and the mid-1990s. At the same time, the between-establishment variance within MOG and 3-digit industry has fallen for both wages \& salaries and benefits. These developments are what we would expect to have seen under the hypothesis of decompression. We should note, however, that despite the recessions in 1982 and 1990, over this twenty-year period taken as a whole the unemployment rate was trending downward. Thus, the patterns we see in the variances could be a reflection of the general tightening of the labor market rather than a more structural change in compensation practices. Indeed, decompression itself could be a response to a sellers' market for workers, with types of workers in shortest supply becoming less willing to trade higher compensation for the long-term stability that may come with wage compression.

To confidently differentiate between structural and "cyclical" characterizations of the patterns in the variances, one would need a longer sample with more cyclical variation, which is not available from the ECI data. Instead, we approached the question by regressing the coefficients on the year variables from the fixed-effects regressions on the demographicallyadjusted unemployment rate. The residuals from these regressions appear in figure 8. These 
residuals exhibit much less of a trend (either upward or downward) than the year coefficients themselves. Of course, the same would be true if we regressed the year coefficients on a time trend, and, in fact, if one regresses the time dummies on both the unemployment rate and a linear trend, the unemployment rate fails to explain any significant portion of the patterns in the variances. These results are far from conclusive, of course, and for now we must leave the question open.

\section{Conclusion}

We have attempted to bring data to bear on the widespread perception that employers have become more flexible in setting compensation, in the sense that the market value of the skills involved in a particular job have become a more important consideration, while the internal distribution of compensation within the firm has become less important. We argue that an increase in flexibility, or "decompression", should manifest itself in an increase in the variance of pay across occupations within establishments, and a decrease in the variance of pay within occupations across similar establishments. While skill-biased technical change, which has been advanced as an explanation for the well-documented increase in earnings inequality across persons in the 1980s, may also predict an increase in the within-establishment variance, it would be more consistent with an increase in the variance within occupations across similar establishments.

We used the underlying micro-data from the Bureau of Labor Statistics' Employment Cost Index program, and find patterns that support the hypothesis of decompression. The variances across occupations within establishments has risen, and, once we abstract from changes in the mix of establishments that make up the sample, the variance within occupations across similar establishments has fallen. Unfortunately for the research, the two decades we are able to study constitute a period of fairly steadily declining unemployment, making it difficult to know whether the patterns we observe are more cyclical or structural in nature. 


\section{REFERENCES}

Akerlof, George A., "Gift Exchange and Efficiency-Wage Theory: Four Views, " American Economic Review, vol. 74 (May 1984, Papers and Proceedings, 1983), p. 79-83.

Akerlof, George A. and Janet L. Yellen, "Fairness and Unemployment", American Economic Review, Vol. 78, No. 2, Papers and Proceedings of the One-Hundredth Annual Meeting of the American Economic Association. (May, 1988), pp. 44-49.

Akerlof, George A. and Janet L. Yellen, "The Fair Wage-Effort Hypothesis and Unemployment," The Quarterly Journal of Economics, Vol. 105, No. 2. (May, 1990), pp. 255-283.

Campbell, Carl M. and Kunal S. Kamlani, "The Reasons for Wage Rigidity: Evidence from a Survey of Firms," Quarterly Journal of Economics 122(3), August 1997, pp. 759-89.

Frank, Robert H., “Are Workers Paid Their Marginal Products?” American-Economic-Review 74(4), September 1984, pages 549-71.

Groshen, Erica L., "Five Reasons Why Wages Vary Among Employers," Industrial Relations 30(3), Fall 1991, pp.350-81.

Hildreth, Andrew K.G. and Andre J. Oswald "Rent-Sharing and Wages: Evindence from Company and Establishment Panels," Journal of Labor Economics, Vol.15, \#2, 1997.

Juhn, Chinhui, Kevin M. Murphy, and Brooks Pierce, "Wage Inequality and the Rise in the Return to Skill," Journal of Political Economy, 101 (June 1993): 410-42.

Lawrence F. and Lawrence H. Summers, "Industry Rents: Evidence and Implications," Brookings Papers on Economic Activity (Microeconomics) (1989):209-75.

Lettau, Michael, "Wage Inflation in the ECI and Across-Group Inequality", BLS Working Paper \#320, January 1999. 
Table 1: Sample statistics (weighted)

\begin{tabular}{|l|c|c|c|c|}
\hline & Mean & Std. deviation & Minimum & Maximum \\
\hline Establishment employment & 2,289 & 10,107 & 1.0 & 631,200 \\
State unemployment rate & 6.5 & 2.0 & 2.2 & 17.7 \\
\hline
\end{tabular}

\begin{tabular}{|c|c|c|c|c|c|}
\hline & & $\begin{array}{l}\text { Percent } \\
\text { of obs. }\end{array}$ & & & $\begin{array}{l}\text { Percent } \\
\text { of obs. }\end{array}$ \\
\hline \multirow[t]{9}{*}{ Industry } & Mining & 1.0 & \multirow[t]{9}{*}{ Occupation } & Prof. \& Technical & 19.4 \\
\hline & Construction & 3.6 & & Exec. \& Admin. & 8.6 \\
\hline & Nondurable & 10.7 & & Sales & 7.4 \\
\hline & Durable & 14.8 & & Admin. support & 18.0 \\
\hline & TCPU & 7.7 & & Precision production & 10.1 \\
\hline & Wholesale & 5.0 & & Machine operators & 11.1 \\
\hline & Retail & 13.5 & & Transportation & 4.2 \\
\hline & FIRE & 5.9 & & Handlers & 7.5 \\
\hline & Service & 37.8 & & Service & 13.7 \\
\hline \multirow[t]{2}{*}{ Union status } & Union & 26.4 & \multirow[t]{2}{*}{ SMSA } & In MSA & 83.2 \\
\hline & Nonunion & 73.6 & & Not in MSA & 16.8 \\
\hline
\end{tabular}

\begin{tabular}{|c|c|c|c|c|c|c|c|c|}
\hline & $\begin{array}{c}\text { \# of } \\
\text { obs. }\end{array}$ & & $\begin{array}{c}\text { \# of } \\
\text { obs. }\end{array}$ & & $\begin{array}{c}\text { \# of } \\
\text { obs. }\end{array}$ & & $\begin{array}{c}\text { \# of } \\
\text { obs. }\end{array}$ \\
\hline Year & 1980 & 6,728 & 1986 & 14,938 & 1992 & 20,752 & 1998 & 16,902 \\
& 1981 & 9,278 & 1987 & 16,461 & 1993 & 20,421 & 1999 & 21,240 \\
& 1982 & 9,030 & 1988 & 17,271 & 1994 & 18,863 & Total & $\mathbf{3 1 9 , 7 1 6}$ \\
& 1983 & 10,164 & 1989 & 21,275 & 1995 & 15,493 & & \\
& 1984 & 11,162 & 1990 & 22,404 & 1996 & 16,464 & & \\
& 1985 & 12,639 & 1991 & 21,560 & 1997 & 16,671 & & \\
\hline
\end{tabular}




\begin{tabular}{|c|c|c|c|c|}
\hline \multicolumn{5}{|c|}{$\begin{array}{c}\text { Table } 2 \\
\text { Panel Regressions of Variances }\end{array}$} \\
\hline & \multicolumn{2}{|c|}{ Within Establishment } & \multicolumn{2}{|c|}{ Across, Within MOG } \\
\hline & $(1)$ & $(2)$ & (3) & (4) \\
\hline & wages & benefits & wages & benefits \\
\hline SMSA & $\begin{array}{l}-.0055^{*} \\
(.0019)\end{array}$ & $\begin{array}{l}-.0005 \\
(.0007)\end{array}$ & $\begin{array}{l}.0049 \\
(.0030)\end{array}$ & $\begin{array}{l}.0068 * \\
(.0023)\end{array}$ \\
\hline UNION & $\begin{array}{l}.0061 * \\
(.0016)\end{array}$ & $\begin{array}{l}.0106 * \\
(.0006)\end{array}$ & $\begin{array}{l}.0036 \\
(.0036)\end{array}$ & $\begin{array}{l}.0124 * \\
(.0028)\end{array}$ \\
\hline LARGE & $\begin{array}{l}.0077 * \\
(.0016)\end{array}$ & $\begin{array}{l}.0022 * \\
(.0006)\end{array}$ & $\begin{array}{l}-.0045 \\
(.0033)\end{array}$ & $\begin{array}{l}-.0018 \\
(.0025)\end{array}$ \\
\hline SMALL & $\begin{array}{l}.0005 \\
(.0022)\end{array}$ & $\begin{array}{l}-.0009 \\
(.0008)\end{array}$ & $\begin{array}{c}.0003 \\
(.0033)\end{array}$ & $\begin{array}{l}.0051 * \\
(.0025)\end{array}$ \\
\hline State u.r. & $\begin{array}{l}-.0007 \\
(.0006)\end{array}$ & $\begin{array}{l}.0006 * \\
(.0002)\end{array}$ & $\begin{array}{l}-.0027 * \\
(.0011)\end{array}$ & $\begin{array}{c}.0004 \\
(.0008)\end{array}$ \\
\hline $\begin{array}{l}\text { Variance } \\
\text { of u.r. }\end{array}$ & -- & -- & $\begin{array}{l}.0064 * \\
(.0006)\end{array}$ & $\begin{array}{l}.0039 * \\
(.0005)\end{array}$ \\
\hline R-square & .18 & .13 & .30 & .32 \\
\hline \# obs & 52,447 & 52,447 & 7,421 & 7,421 \\
\hline $\begin{array}{l}\text { Notes: Ea } \\
\text { major occ } \\
\text { dummies. } \\
* \text { indicate }\end{array}$ & regressio & ncludes $m$ & $\begin{array}{l}\text { jor industr } \\
\text { fects, and } \\
\text { parenthes } \\
\text { vel. }\end{array}$ & lummies, \\
\hline
\end{tabular}


Figure 1

\section{Mean and Variance of Voluntary Compensation}
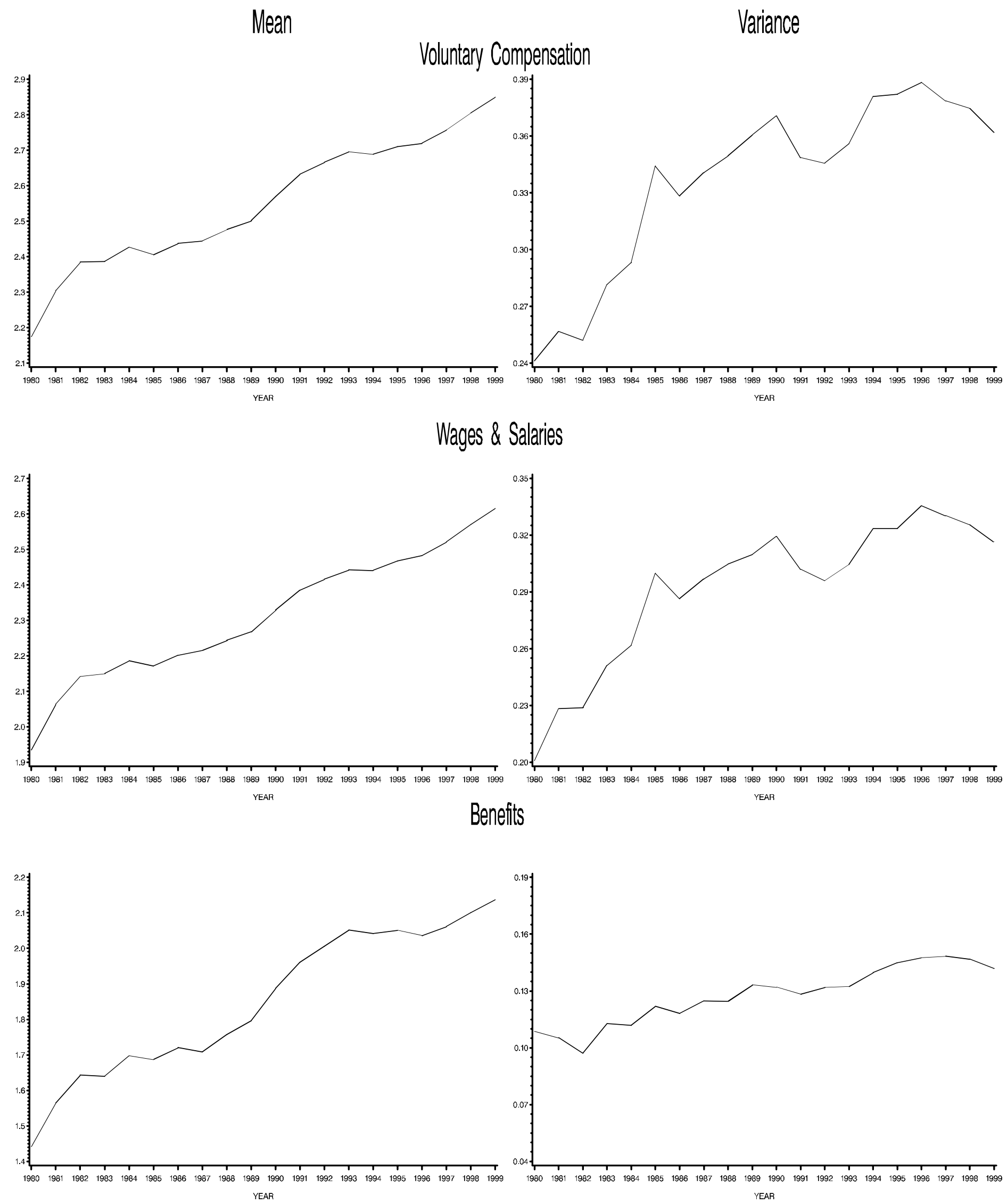
Figure 2

Variance Within Establishment

Variance Across Estabishments

\section{Wages \& Salaries}
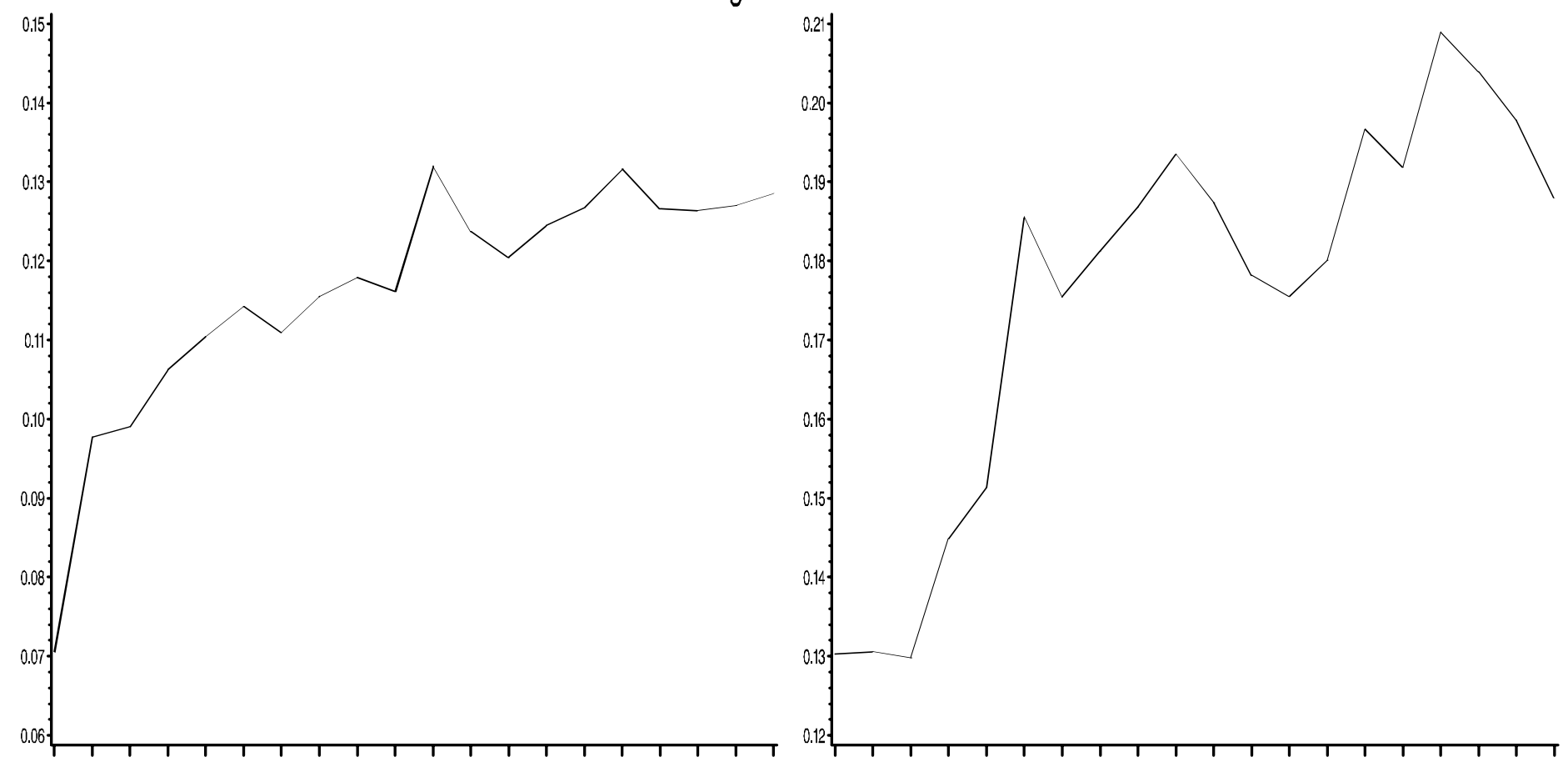
$19801981198219831984198519861987198819891990199119921993199419951996199719981999 \quad 19801981198219831984198519861987198819891990199119921993199419951996199719981999$ YEAR

\section{Beneifts}

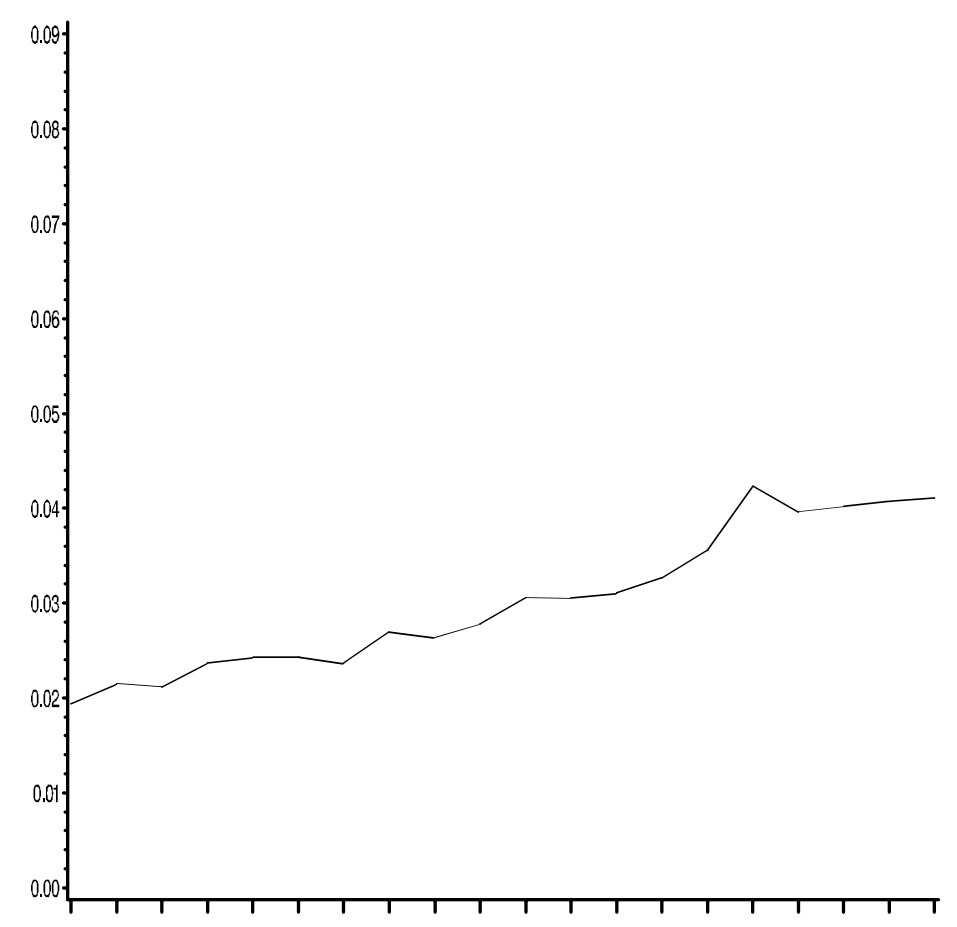

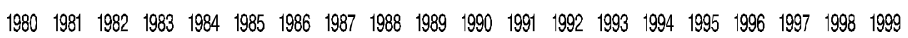

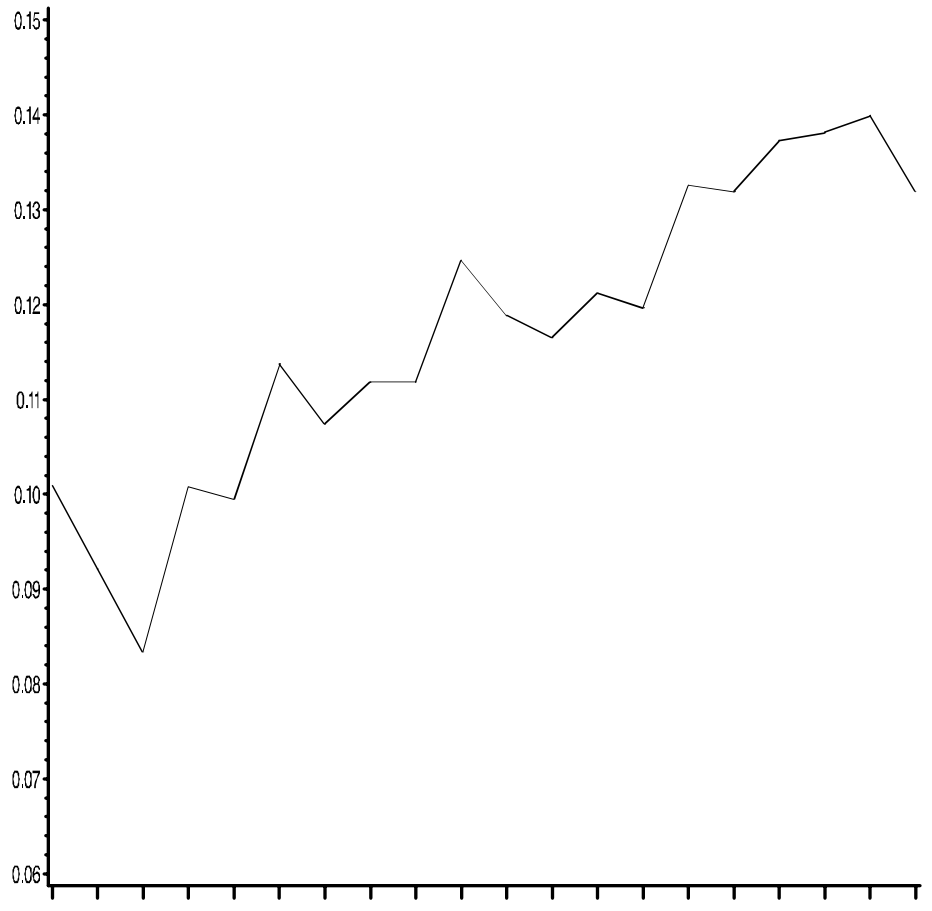

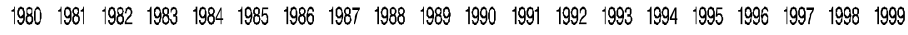


Figure 3

Attribution of Variance
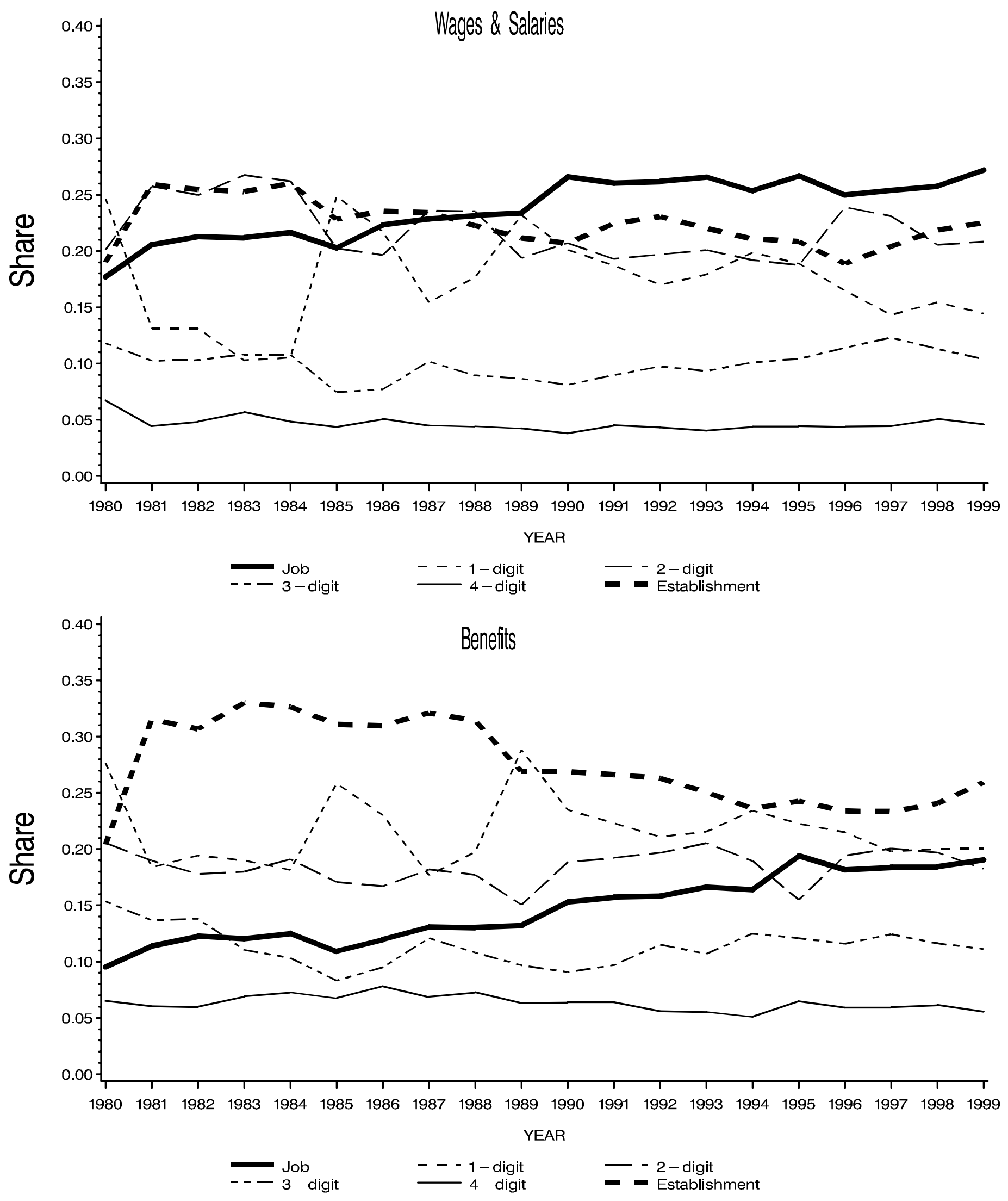


\section{Figure 4}

\section{Variance Across Establishments, Within MOG \& Indusiny}
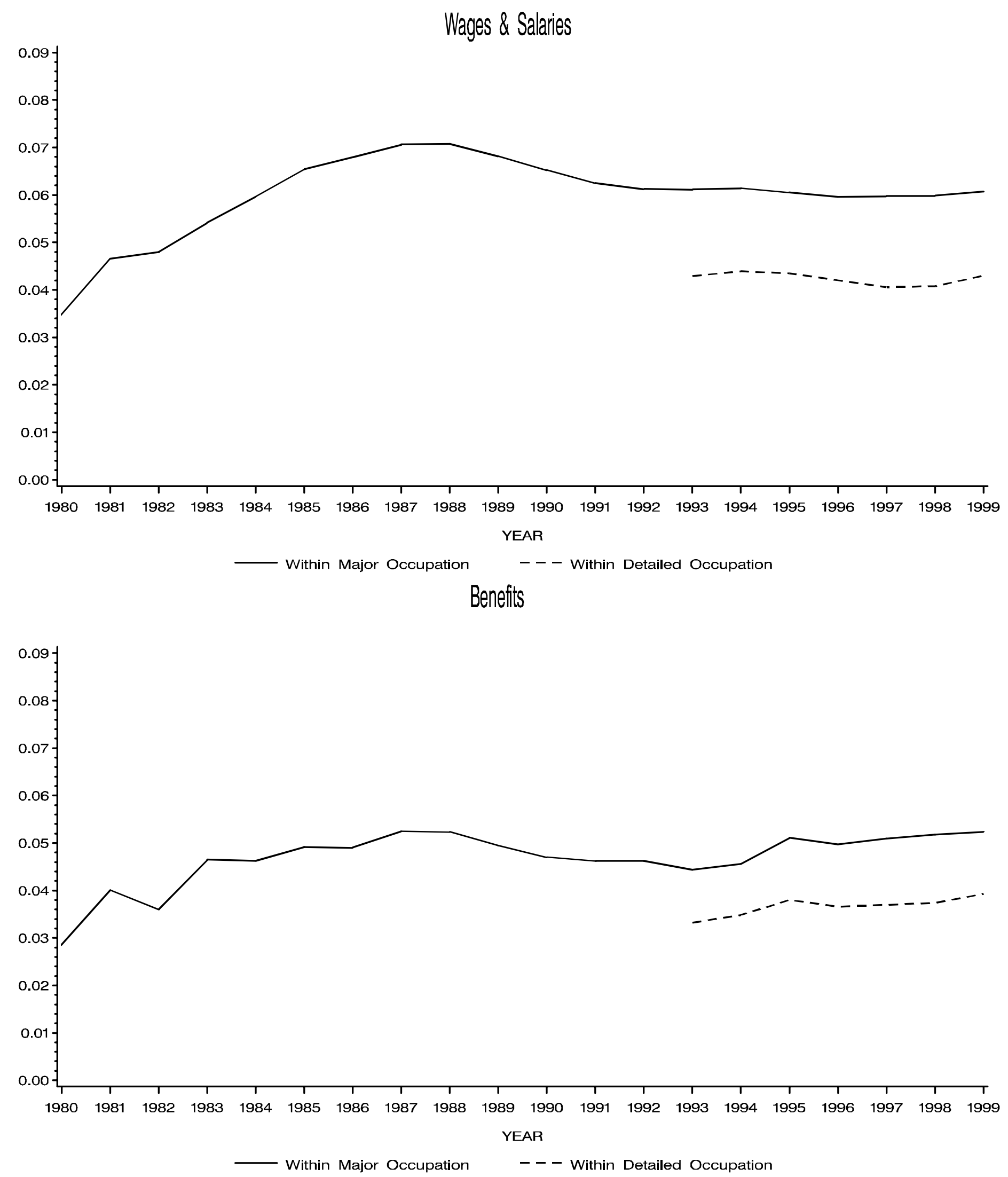
Figure 5

Regression Coefficients on Year Variables

Dependant Varable $=$ Variance Within Essiablishment
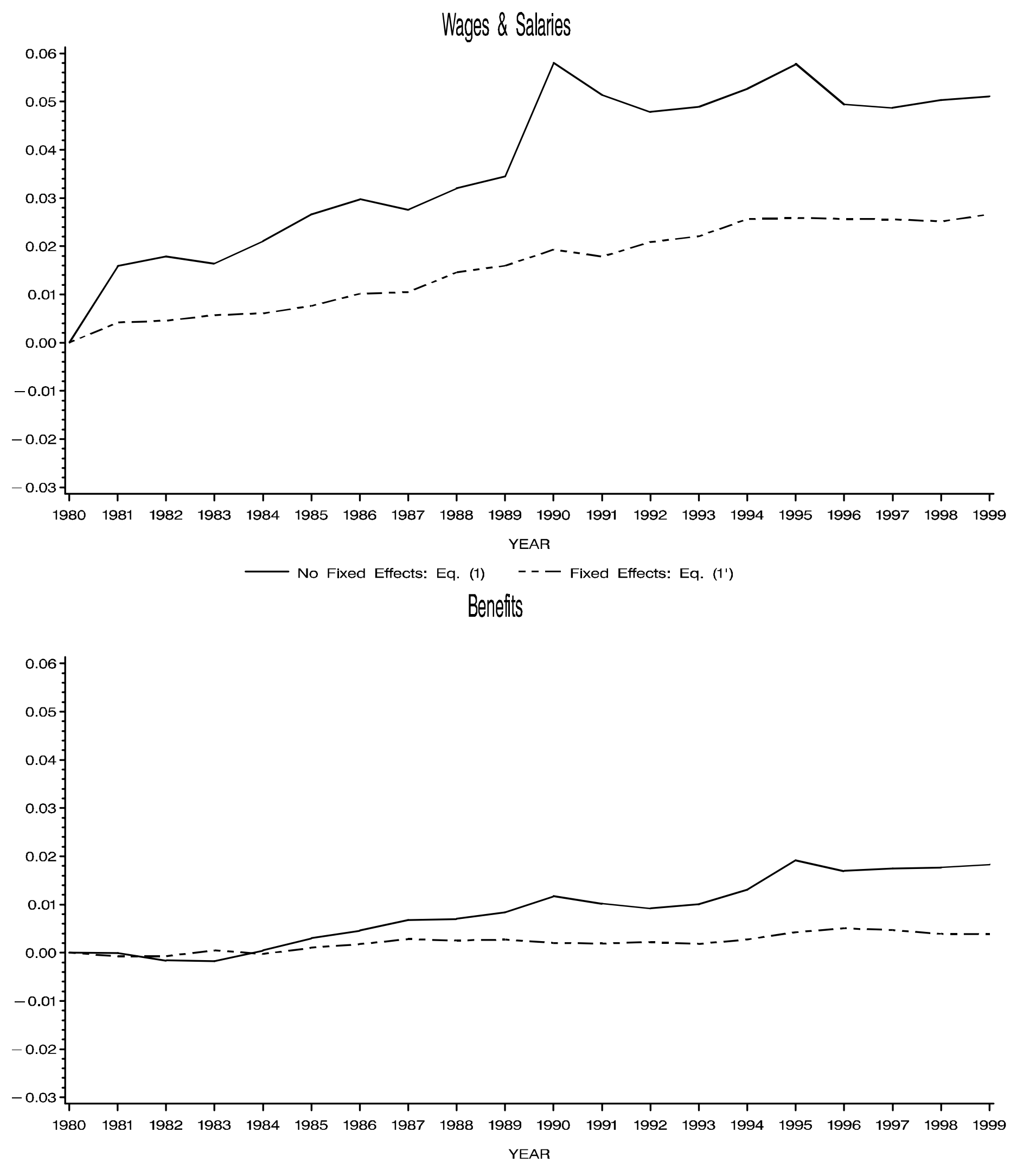

- No Fixed Effects: Eq. (1) - - Fixed Effects: Eq. (1') 
Figure 6

Regression Coefficients on Year Variables

Dependant Variable $=$ Variance Within Establishment

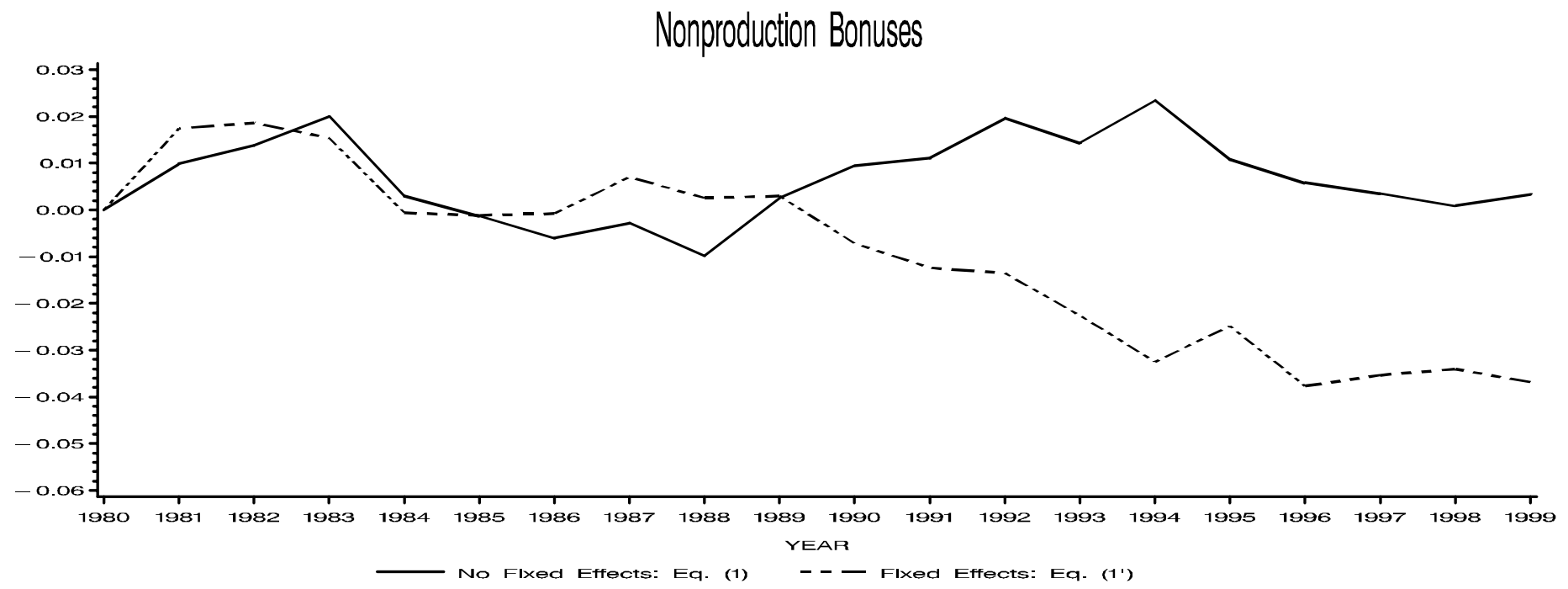

\section{Retirement \& Savings}

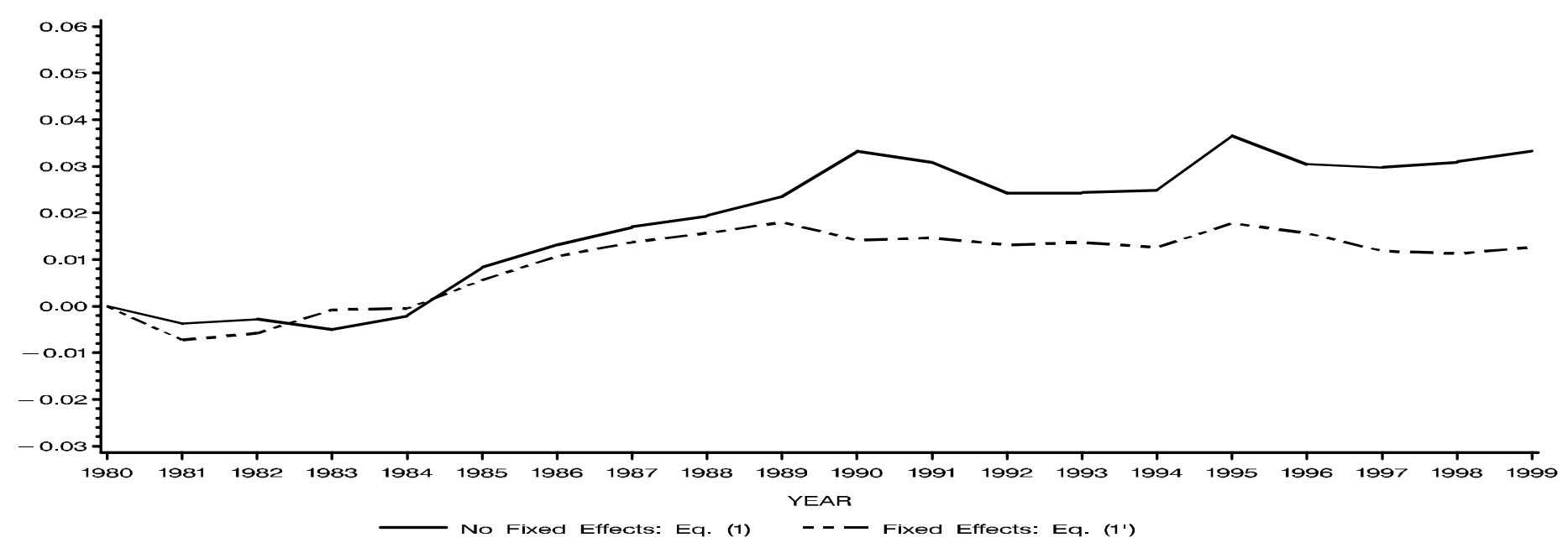

\section{Health Insurance}

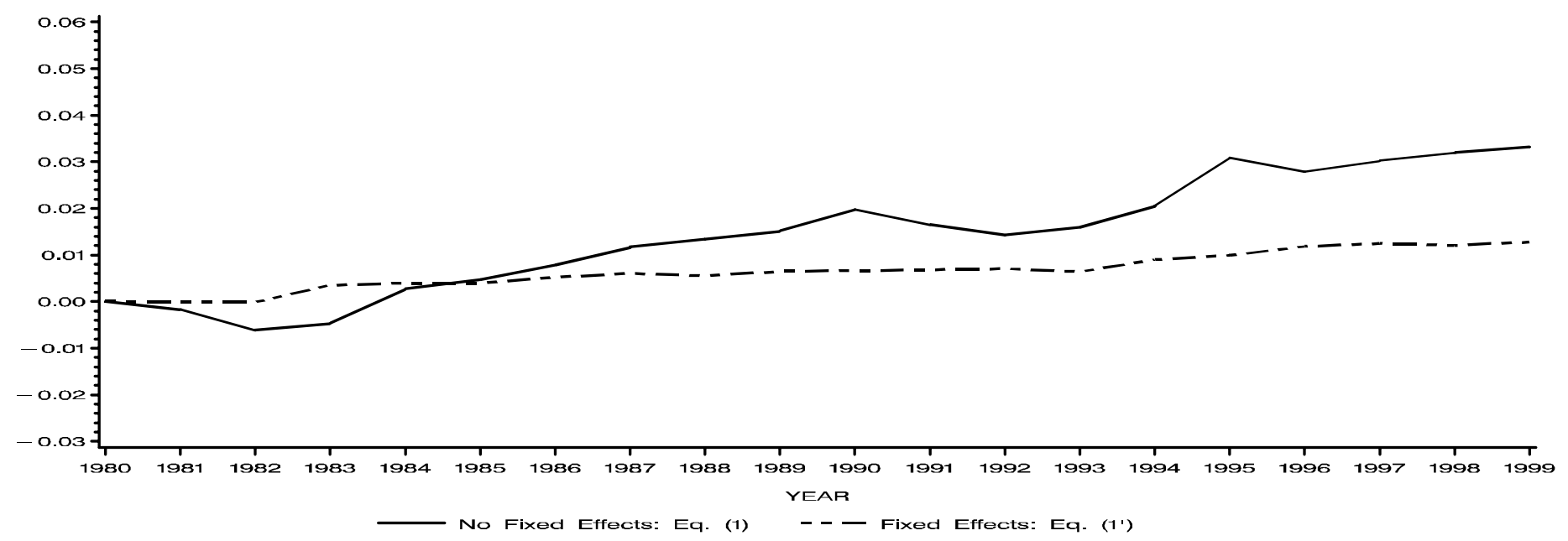


Figure 7

Regression Coefficients on Year Variables

Dependant Variable $=$ Variance Across Estabishments, Within 3-Digit Industry \& MOG
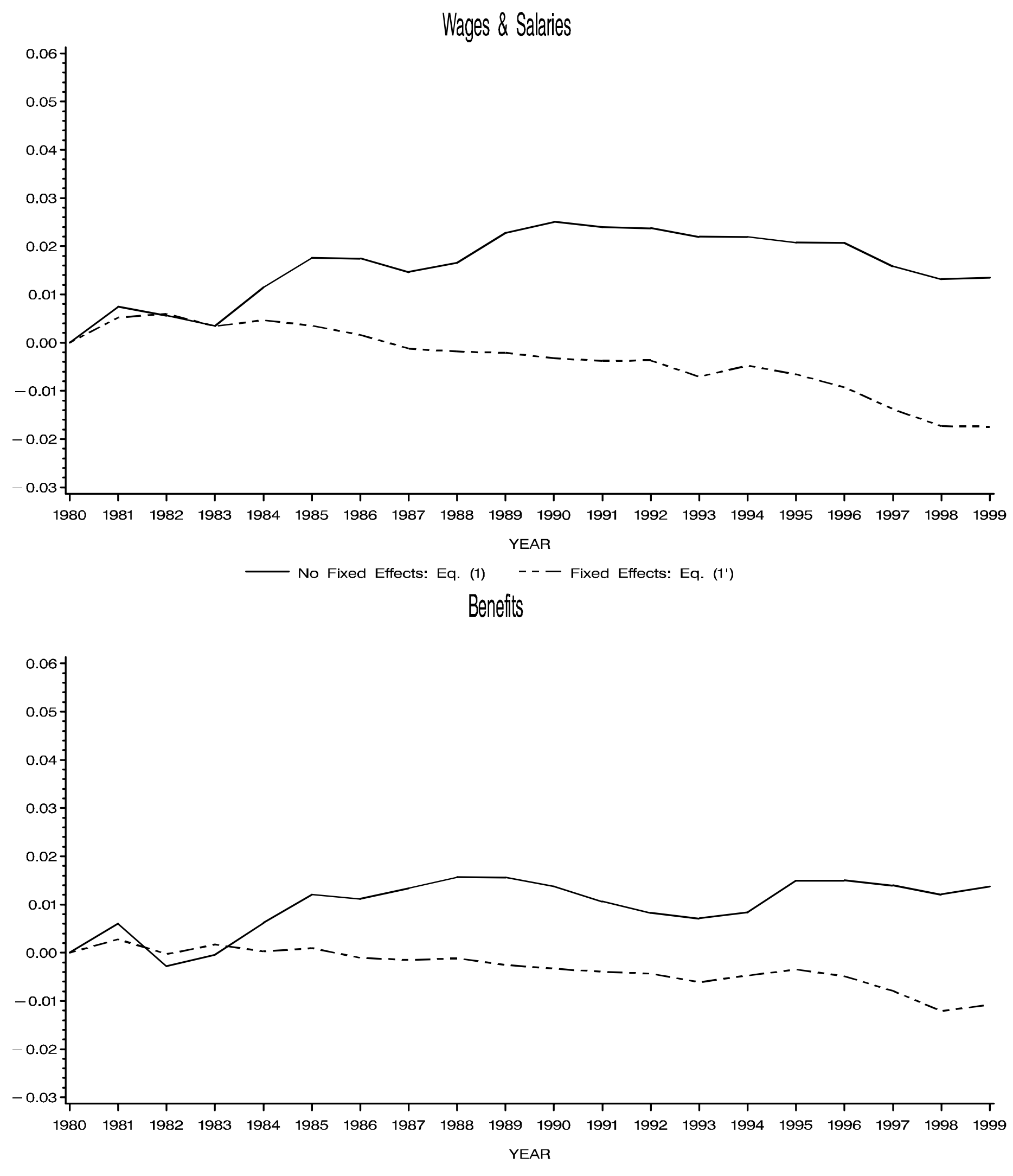

No Fixed Effects: Eq. (1) - - Fixed Effects: Eq. (1') 

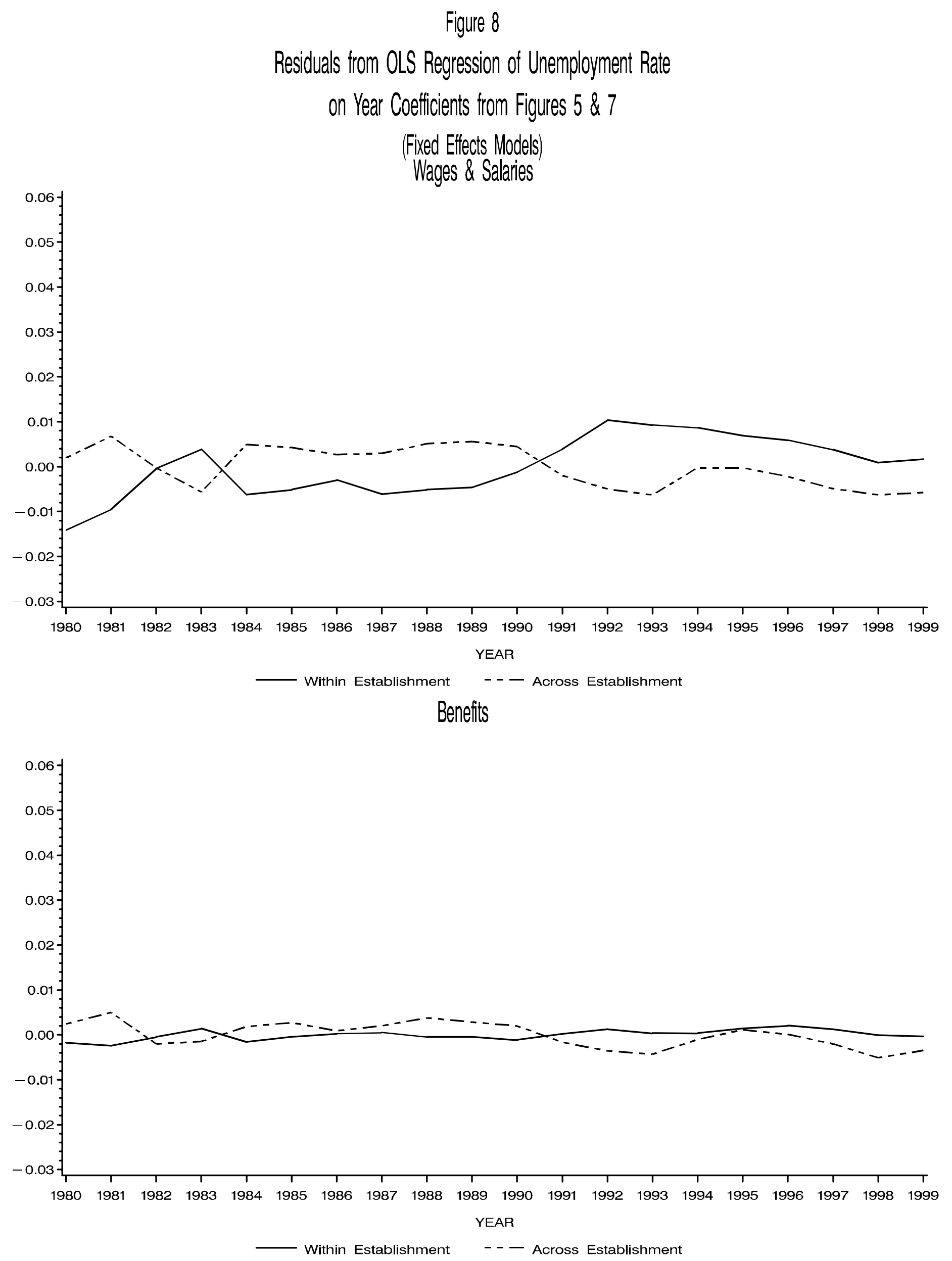